\title{
APP-071 膀胱及び中枢神経ニコチン，ムスカリン受容体刺激の排尿反射に及ぼす影響の比較
}

\author{
東京医科歯科大学医学部泌尿器科1), ピッツバーグ大学泌尿器科"2), ピッツバーグ大学薬理学 ${ }^{3)}$
}

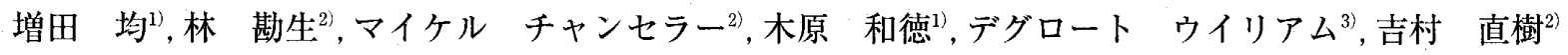

目的】ニコチン，ムスカリン両受容体が尿路上皮，中枢神経系に発現している事から，両受容体が排尿の求心路に機能的役割を果たしている

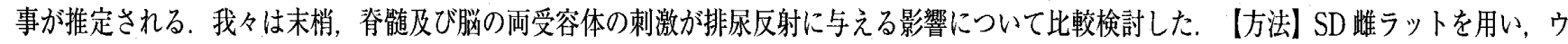
レタン麻醉下に膀脱内圧測定を施行。ニコチン受容体刺激剂のニコチン，ムスカリン受容体刺激敦の oxotrmoline-M $(0 X 0-M)$ ，コリンエステ

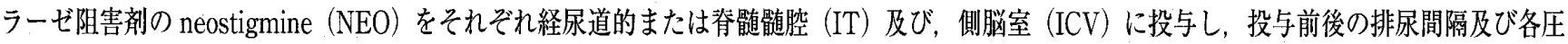
パラメーターの比較を行った．また，膀胱壁にファストブルーを投与し，L6～S1 の後根神経節から同陽性細胞を単離し，その中でカプサイシ ン感受性細胞に対するニコチン， OXO-M の反応をパッチクランプ法を用いて檢討した. 【結果】ニコチン $(1 \sim 10 \mathrm{mM})$ 及び OXO-M (10〜 $100 \mu \mathrm{M})$ の膀胱内灌流は，それぞれ排尿間隔を漲度依存性に短縮し，この変化はそれぞれニコチン受容体拮抗剤である mecamylamine (MEC,3

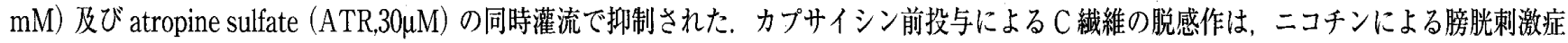
状は抑制したが，OXO-Mによるそれには影響を与えなかった，パッチクランプ法で, ニコチンはカプサイシン感受性細胞で内向き電流を惹起

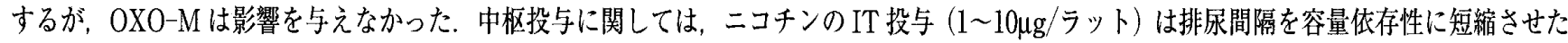

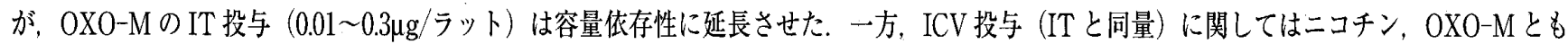
に排尿間隔を容量依存性に延長させた。 OXO-M の中枢反応（IT,ICV ともに）は，ATR 及びMl 受容体阻害剂の pirenzepine の前投与で抑制 されたが，M2 阻害剂の methoctramine,M3 阻害剤の 4-DAMPでは有意な影響を受けなかったまた，NEO の IT,ICV 投与（雨者とも0.01〜3 $\mu \mathrm{g} /$ ラット)とも容量依存性に排尿間隔を延長させ, 同反応は ATR,pirenzepine の前投与で抑制されたが, MEC では有意な影響を受けなかった. 【結論】膀脱におけるニコチン，ムスカリン受容体の興奮はともに排尿反射を促進し，頻尿を誘発すると考えられえた，前者は，カプサイシン

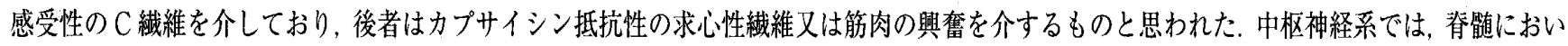
てニコチン受容体の刺激注排尿反射を刺激する一方，ムスカリン受容体刺激は M1 受容体を介して排尿反射を抑制した。脳では，両受容体の刺 激とも排尿反射を抑制した．コリンエステラーゼ阻害による内因性アセチルコリンの蓄積は，M1 受容体を介して排尿反射を抑制した事から， 中枢のアセチルコリンは，少なくとも正常状態では，ムスカリン受容体を介して排尿反射を制御している可能性が示唆された．

\section{APP-072 NO/cGMP の腤胱平滑筋組織の収縮作用機序の解明}

\section{名古屋市立大学大学院医学研究科腎泌尿器科学講座1), 名古屋市立大学大学院医学研究科細胞機能制御学 ${ }^{2}$}

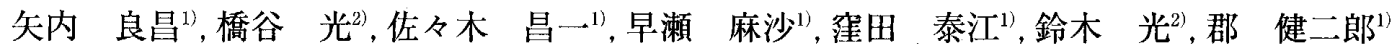

【目的】NOは，尿道，陰茎海綿体などの平滑筋を驰紘させる，膀腅平滑筋では，NOの作用はこれまで，収縮，弛緩どちらの報告 もが混在している，膀胱平滑筋組織で NOにより平滑筋細胞では cGMPが増加しなという報告もあり，膀胱に特異的な NO/ cGMP の作用機序があれば OAB 治療などへつながる可能性があると考え，この点について検討した.【方法】モルモット膀胱平 滑筋標本で，細胞内電位記録と等尺性張力記録を行った【結果】 SIN-1 や SNP といったNO 供与体は自発活動電位の振幅を変 化させず頻度を增加させ，また自発収縮の頻度と振幅を增加させた．これらの反応は guanylate cyclase 阻害郕 (ODQ)では抑制 されなかった. また神経伝達物質の阻害剤や，塩素イオンチャネルのブロッカーであるニフルム酸, 非選択的陽イオンチャネルの ブロッカーであるSKFでも消失しなかった， しかし細胞内Ca 貯蔵部位 (SR)の阻害刘 (CPA や Ryanodine)により抑制された. また Sildenafil は単平滑筋片標本の自発收縮や自発練胞内電位变化には影響を与えなかったが, 多平滑筋片標本の収縮を抑制し た，多平滑筋片標本の自発収綃には振幅にばらつきがあるが, Sildenafil でこのうちの最小単位の振幅の自発収縮は残存した.

【結論/考察】平滑筋はNOにより guanylate cyclase が活性化され，cGMP が増加して弛緩作用を示すとされている．本実験では guanylate cyclase を抑制する ODQでも NO 供与体による興奮作用が消失しなかった．しかし 8bromo-cGMPでは自発活動の発 生頻度を低下させることが知られており，膀胱平滑筋細胞ではNO の作用はcGMPに依存しない興奮作用を有している可能性が 示唆された. この平滑筋細胞の興奮性作用には SR からの Ca 放出が関与しているようであった. 膀胱平滑筋の周囲には間質細胞 や神経終末が多数存在している. NO 供与体により平滑筋細胞では cGMP は増加しないが, その周囲の細胞では増加するという報 告があり，NOに対する作用が間質細胞と平滑筋䋖胞では異なるのかもしれない，それにより通常神経終末から放出される NO に対しては間質紐胞の cGMP 情報伝達系を介して弛緩反応が生じるが，NO供与体投与により平滑筋紏胞自体の興奮作用が顕著 に見られたのかもしれない，Sildenafilによる反応も平滑筋細胞のみでは cGMPが関与しないため変化を来さず, 平滑筋周囲の細 胞が多いと間質細胞などで cGMPが増加することでその機能が抑制され，平滑筋片間の収縮の同期性が減少し，弛緩反応が現れ たと考えられる. 今後, 細胞間情報伝達系としての間質細胞を標的とした Sildenafil のOAB 治療への応用が期待される. 